\title{
A Support System for Mouse Operations Using Eye-Gaze Input
}

\author{
Kiyohiko Abe Member (College of Engineering, Kanto Gakuin University, abe@kanto-gakuin.ac.jp) \\ Yasuhiro Nakayama Non-member (School of Engineering, Tokyo Denki University) \\ Shoichi Ohi Non-member (School of Engineering, Tokyo Denki University) \\ Minoru Ohyama Non-member (School of Information Environment, Tokyo Denki University)
}

Keywords: Eye-gaze input, Mouse operation, Under natural light, Image analysis, Limbus tracking method

Recently, several eye-gaze input systems have been reported as a novel human-machine interface. The operation of these systems only requires user's eye movement. Most of them operate under infrared light. We have developed an eye-gaze input system for people with severe physical disabilities, such as amyotrophic lateral sclerosis (ALS) patients. This system utilizes a personal computer and a home video camera to detect eye-gaze under natural light. The system detects both vertical and horizontal eye-gaze by simple image analysis, and does not require special image processing units or sensors. Our conventional eye-gaze input system can detect horizontal eye-gaze with a high degree of accuracy. However, it can only classify vertical eye-gaze into 3 directions (up, middle and down).

In this paper, we propose a new method for vertical eyegaze detection. This method utilizes the limbus tracking method for vertical eye-gaze detection. Therefore our new eye-gaze input system can detect the two-dimensional coordinate of user's gazing point. By using this method, we develop a new support system for mouse operation. This system can move the mouse cursor to user's gazing point.

Our image analysis software on the personal computer analyzes eye images taken by a video camera. The overview of horizontal and vertical detection are shown in Fig.1(a) and Fig.1(b) respectively.

Our eye-gaze detection methods use the difference in reflectance between the iris and the sclera; this is estimated by the difference of integral value of the brightness on two areas placed in eye image (area A and B or area C and D). These methods are based on the limbus tracking method. The difference of integral value of the brightness is defined as eye-gaze value. The eye-gaze value and the angle of sight are nearly proportional. Therefore, if the eye-gaze input system is calibrated using this relation, the horizontal and vertical eye-gaze can be estimated. Concretely speaking, the two-dimensional position of user's gazing point is decided by these processes.

We also developed a support system for mouse operations using proposed eye-gaze detection methods, shown in Fig.2. This system can move mouse cursor near the user's gazing

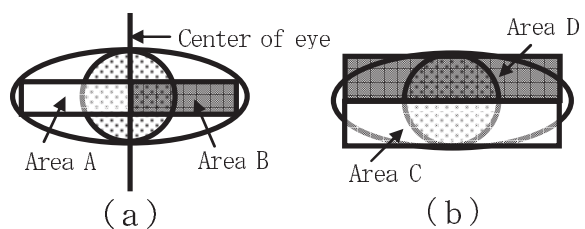

Fig. 1. Detection of horizontal(a) and vertical(b) eye-gaze.

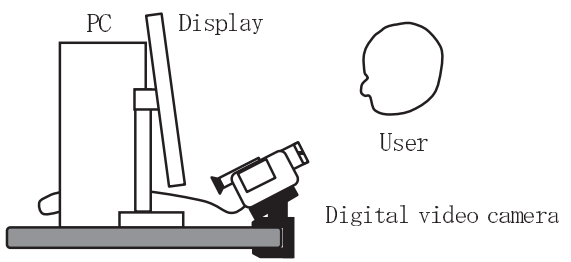

Fig. 2. Hardware configuration.

point. While mouse cursor is moving by eye-gaze, the trajectory of cursor movement has vibration caused by involuntary eye movement or measurement errors. Hence, it is difficult to move mouse cursor smoothly by eye-gaze.

We confirmed in previous experiments that if the trajectory of mouse cursor lacks smoothness, it is difficult to move the mouse cursor to the destination on screen properly. Therefore, we calculated a three-dimensional spline curve first, and then made mouse cursor move on the spline curve. This spline curve is estimated by the three positions of eye-gaze, one of them is current position and two of them are past positions. As a result, mouse cursor moves in smooth, and the system operability is increased.

We conducted the evaluation experiments for the proposed system with five subjects. The result shows that the mouse control by eye-gaze requires quadruple time compared to the operation by hand, however we confirmed that the mouse cursor can be operated certainly by eye-gaze only. When the system is used for practical purposes, the user can adjust the position of mouse cursor using hand. Therefore, the user can select objects faster than experimental condition. 


\title{
視線によるマウス操作補助システム
}

\author{
正 員 阿部 清彦* 非会員 仲山 泰弘** \\ 非会員 大井 尚一** 非会員 大山 実***
}

\author{
A Support System for Mouse Operations Using Eye-Gaze Input \\ Kiyohiko Abe*, Member, Yasuhiro Nakayama**, Non-member, Shoichi Ohi**, Non-member, \\ Minoru Ohyama***, Non-member
}

We have developed an eye-gaze input system for people with severe physical disabilities, such as amyotrophic lateral sclerosis (ALS) patients. This system utilizes a personal computer and a home video camera to detect eye-gaze under natural light. The system detects both vertical and horizontal eye-gaze by simple image analysis, and does not require special image processing units or sensors. Our conventional eye-gaze input system can detect horizontal eye-gaze with a high degree of accuracy. However, it can only classify vertical eye-gaze into 3 directions (up, middle and down). In this paper, we propose a new method for vertical eye-gaze detection. This method utilizes the limbus tracking method for vertical eye-gaze detection. Therefore our new eye-gaze input system can detect the two-dimension coordinates of user's gazing point. By using this method, we develop a new support system for mouse operation. This system can move the mouse cursor to user's gazing point.

キーワード : 視線入力, マウス操作, 自然光下, 画像解析, 強膜反射法

Keywords: Eye-gaze input, Mouse operation, Under natural light, Image analysis, Limbus tracking method

\section{1. はじめに}

近年, 人間の視線方向の変化を捉え, それによりコンピ ュータヘコマンドや文字などを入力する視線入力に関する 研究がさかんに行われている(1) (10)。視線入力は, 眼球や まぶた以外の運動を必要としないので, 重度の ALS（筋萎 縮性側索硬化症）患者のように運動機能を著しく制限され ている人たちも使用が可能であり，これを利用した支援シ ステムにより他者とのコミュニケーションなどを，より効 果的に行うことができる。

\footnotetext{
$*$ 関東学院大学工学部情報ネット・メディア工学科

厂 263-8501 横浜市金沢区六浦 1-50-1

College of Engineering, Kanto Gakuin University

1-50-1, Mutsuurahigashi, Kanazawa-ku, Yokohama, 2368501

** 東京電機大学工学部電気電子工学科

干 101-8457 東京都千代田区神田錦町 2-2

School of Engineering, Tokyo Denki University

2-2, Kandanisiki-cho, Chiyoda-ku, Tokyo, 101-8457

*** 東京電機大学情報環境学部情報環境学科

干 270-1382 印西市武西学園台 2-1200

School of Information Environment, Tokyo Denki University

2-1200, Muzaigakuendai, Inzai-shi, 270-1382
}

視線入力には, 計測の容易さから画像解析を応用した非 接触の方法が多く採用されており, その光源として赤外 光 (1)〜(6) または, 室内照明などの自然光 ${ }^{(7) \sim(14)}$ が使用さ れている。前者は入力精度は高いが特殊な装置を必要とす る。後者は特殊な装置は不要であるが入力精度が低い傾向 があり, 複数台のカメラを用い, 頭部の移動を許容して視 線計測の高精度化を図っているものもある (13)(14)。個人が 自由に使用できることを想定すると, 安価で設置が簡単な 1 台のカメラとパソコン程度の装置で構成されるシステム が望ましい(7) (10)。

著者らは重度肢体不自由者の頭部移動が大きくないこと に着目し, 自然光の照明（蛍光灯照明）のもとに, 家庭用 ビデオカメラ 1 台とパソコンのみを用いて, 画像処理によ

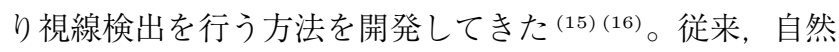
光下で 1 台のカメラを用いる手法の場合, 識別できる指標 数はたかだか数個程度である(8) (10) のに対し, 著者らの開 発してきたシステムは水平 $9 \times$ 垂直 3 の計 27 個という多 数の指標を注視点計測によって識別することができる ${ }^{(16)}$ 。

このシステムのアプリケーションとして， Web ブラウ ザを操作し Web ページの閲覧など情報収集を行うシステ ム ${ }^{(17)}$ や, 日本語などの文字入力や汎用的なパソコン (Windows XP) 操作が可能なパソコン操作システム (18) などの 
応用プログラムを開発してきた。

著者らの開発してきた視線入力の従来システムは, 水平 方向の計測は高精度に行えるものの, 垂直方向は上中下の 3 段階で識別をしてきた。垂直方向の計測分解能が向上す れば，画面に表示できる指標数を増やすなど，より使いや すく汎用性の高いインタフェースを構築することができる。 画面に表示する指標数を増やすためには，一般にキャリブ レーションに必要な注視指標の数も増加し操作が煩雑にな る傾向がある。しかしながら，たとえば 1 画面に表示でき る指標数が制御用キーを含めて 60 個程度あれば，画面の切 り替えなしに日本語を自由に入力でき ${ }^{(3)}$ ，操作性は向上す る。この目的のために, 著者らは水平方向の計測に使用し ている強膜反射法を垂直方向にも適用することにより，注 視点の 2 次元座標值を計測する手法を開発した。

一般的にパソコンなどで GUI を装備した OS を操作する 際，ユーザは操作対象であるアイコンやウィンドウなどに 視線を向けている。すなわち，それらオブジェクトを注視 している。ユーザの注視点近傍へ自動的にマウスカーソル を移動させることができれば，ファイルやウインドウの選 択などのマウス操作をより効率的に行うことができる。著 者らは，新しい注視点座標の計測法を用いて，パソコンの ディスプレイ上におけるユーザの注視点近傍へマウスカー ソルを移動させるマウス操作補助システムを開発した。こ の種のシステムは，重度肢体不自由者のためのコミュニケー ション支援に用いることができるほか，健常者がパソコン を操作する際の補助システムとしての活用を期待できる。 以下，新たに開発した垂直方向視線計測法と，それを応用 した視線によるマウス操作補助システムについて，被験者 5 名による評価実験の結果とあわせて報告する。

\section{2. 画像解析による視線入力}

近年の画像処理技術の向上により，ビデオカメラなどで撮 影された眼球画像から視線を計測するさまざまな手法が提 案されている ${ }^{(2) \sim(20)}$ 。それらのうち, 自然光下で計測を行 う方法では虹彩の位置情報を用いるものが多い (7) (12) (19)。 しかしながら, 虹彩と強膜のエッジはなだらかに変化して おり，虹彩を正確に抽出することは難しい。また虹彩の半 分ほどがまぶたの下に隠れてしまう人もあり，虹彩を円近 似しその位置を捉えることが困難な場合がある。赤外線を 用いた手法では，虹彩よりも小さくまぶたに隠れにくい睹 孔を用いて計測を行う方法があるが，瞳孔であっても円近 似が難しい場合があると指摘されている ${ }^{(20)}$ 。

著者らはこれらの点に対処するため, 自然光下でビデオ カメラにより撮影された眼球近傍画像から，強膜反射法を 応用した画像解析によって，水平および垂直両方向の視線 を計測することとした。著者らの提案する手法では，家庭 用ビデオカメラで撮影された眼球近傍の動画像をパソコン に取り込み,ソフトウェアによる処理で静止画として取得 している。Fig. 1 に処理対象となる眼球画像の一例を示す。 なお眼球画像を撮影する際には，プレビュー画面として計

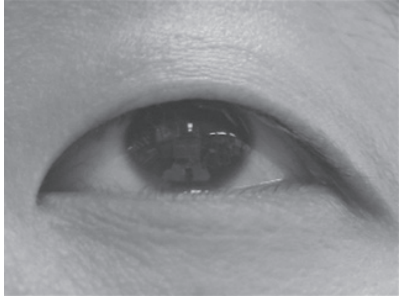

Fig. 1. An example of eye image.

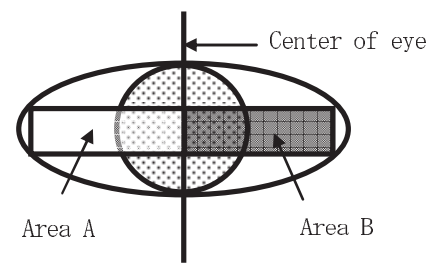

Fig. 2. Detection of horizontal eye-gaze.

測領域を重ね合わせた画像をパソコンのモニタに表示して いる。

$\langle\mathbf{2} \cdot \mathbf{1}\rangle$ 水平方向視線計測 水平方向（左右方向）の視 線検出法の概念図を Fig. 2 に示す。光強度（カラー画像を モノクロ変換したグレースケール值）を積分する領域を A およびBのように設定し，この領域における光強度積分值 （総和）の差を求めると, 水平方向の視線方向に対し一意 にある值（以後，視線值とよぶ）を得る。視線值と視線方 向の移動量（視角）はほぼ直線的な関係になるため, ユー ザごとにキャリブレーションでこの直線を求めると, 視線 計測時に得られる視線值から水平方向の注視位置を求める ことができる(15) (16)。具体的には，計測前に水平で等間隔 (視角も等間隔) に並んでいる 3 個の指標を注視し, 計測さ れた視線值から最小二乗法を用いて近似直線を得る。その 後, この近似直線と計測值を比較することにより，ユーザ の注視位置を求める。

Fig. 2 に示した領域 A および B，それにそれらを分割す る中心線は眼球画像撮影時のモニ夕に重ね合わせて表示さ れており，計測前にこれらの領域が眼球開口部に適切に設 定されるようカメラ位置などを調節している。

$\langle 2 \cdot 2\rangle$ 垂直方向視線計測著者らの従来システムで は, 垂直方向 (上下方向) の視線を計測する際に, キャリブ レーション時に撮影された眼球画像から水平方向の 1 次元 射影を求め，それを基準データとしてマッチングによるパ ターン認識を行っていた ${ }^{(16)}$ 。この手法では, 識別できる指 標数に対応した数の基準デー夕を準備する必要があり，シ ステムの垂直方向の指標数を増やす際にキャリブレーショ ンの負担が大きくなった。

垂直方向の計測においても，水平方向と同様の視線計測 特性を求めてキャリブレーションを行うことができれば，よ り高精度の垂直方向視線計測が可能となる。垂直方向の視 線移動においても, 水平方向と同様に虹彩の移動が生じる ため同様の計測手法が適用できる。しかしながら，垂直方 


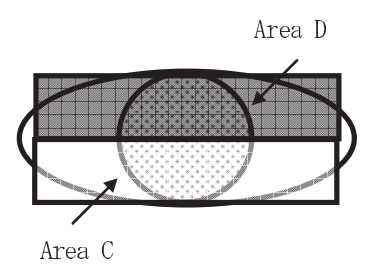

Fig. 3. Detection of vertical eye-gaze.

向の視線計測に抢いては，視線の移動により上下のまぶた の位置が変化する。そのため, 水平方向と同様に計測領域 の位置を固定し計測を行うと, 計測領域に眼球以外の部分 すなわち皮虐が大きく入り込んでしまい，視線を高精度に 計測することが困難になる。

この点に対処するため，著者らは上下まぶたの位置を画 像解析によって取得し, 眼球開口部に計測領域を設定するこ とにした。具体的には $\langle 2 \cdot 3\rangle$ 節で述べる眼球形状抽出法 ${ }^{(16)}$ を用い，抽出された眼球形状から上下のまぶたの端点を求 め，その位置を計測領域の上下辺の位置とする。これによ り，視線が垂直方向に移動しても計測領域はたえず眼球開 口部内にあるため，まぶたの形状変化による計測精度の低 下を抑えることができる。垂直方向の視線検出法の概念図 を Fig. 3 に示す。

垂直方向の計測では，計測領域を領域 $\mathrm{C}$ および $\mathrm{D}$ のよ うに配置する。そして，それぞれの領域における光強度積 分值の差を求めると, 水平方向と同様に視線方向に対しほ ほ直線的な変化を示す。これにより, 垂直方向の注視位置 を求めることができる。

$\langle 2 \cdot 3\rangle$ 頭部移動の検出とその補正 著者らが提案する 視線検出法では, 観察点であるビデオカメラを眼球から離 れた位置に設定し，眼球近傍を拡大して撮影する。そのた め, 頭部の微小な移動（ゆれ）により大きな計測誤差を生 じる。この誤差を軽減するには，頭部移動を検出し補正す る必要がある。著者らは, 視線移動によっても形状変化が 少ない目頭の位置をリアルタイムに捉えることにより，頭 部移動を検出する手法を採用した。

目頭の位置を決定し追跡するには, 眼球形状を何らかの 方法で撮影した眼球近傍画像から抽出し，その端点（正確 には，顔の中心に近いほうの端点）を求めればよい。眼球 形状を抽出するには，たとえばカラー情報の特徵を用いた 2 值化処理によって, 眼球の部分とそうでない皮膚の部分 に分ければよいが，このときに目頭近傍に小さくても汗や 皮虐上のしわなどにより明るい反射光が写り込んでいると， それがノイズとなり皮膚の部分であるのに眼球の一部であ ると誤認識される場合がある。

このことに対処するには, 別の方法を併用して目頭を捉 える必要がある。目頭は言い換えると上まぶた，または下 まぶたの端点であり，その位置を求めても目頭の位置を決 定することができる。つまり何らかの手法を用いて目頭近 傍のまぶたを抽出し，それを辿り端点を見つければよい。 著者らはこの目的のため眼球画像に特殊な微分フィル夕処

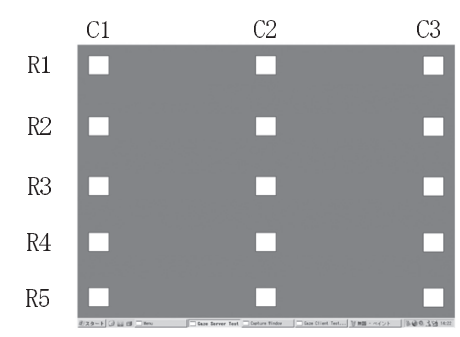

Fig. 4. Indicators for eye-gaze measurement.

理を施すことにより，上まぶたに相当する目頭近傍のエッ ジを抽出する手法を案出した。しかしながらこの手法を用 いた場合, 抽出されたまぶたの端点近傍のエッジは光強度 がなだらかに変化しているため, 端点の決定にはしきい值 が必要となり,この処理画像のみでは目頭位置の自動決定 はできない。そのため, 上述の 2 值化処理結果と目頭近傍 のエッジ抽出結果の二つから, 目頭の位置を決定する手法 を開発した ${ }^{(16)}$ 。

求められた目頭位置から, 頭部の移動距離と方向を求め ることができ，これをもとに計測領域の位置を補正し注視 点計測誤差を減少させている。なお本手法では, 撮影画像 から眼球が外れない範囲（上下左右約 1 七ンチ）の頭部移 動において, 確実に頭部移動の補正がリアルタイムにでき る。またここの頭部移動補正法を用いた視線入力システム は、ヘッドレストを使用するなどで軽く頭部を固定して使 用することを想定している。そのため通常の使用環境では, 頭部が大きく移動し撮影画像上から眼球が外れることはな い。長時間にわたる使用で頭の位置が大きく移動するなど により，眼球全体を撮影できない状況になった場合は，ビ デオカメラの位置を調整し再キャリブレーションを実行す る。そのため, キャリブレーションはなるべく簡易な方法 が要求される。

本手法により得られた眼球形状画像をもとに，〈2・2 節で 述べた垂直方向視線計測に扔ける計測領域を決定している。

$\langle\mathbf{2} \cdot \mathbf{4}\rangle \quad$ 視線計測特性 $\langle 2 \cdot 1\rangle$ 㧍よび $\langle 2 \cdot 2\rangle$ 節で述べた 視線計測法を用い，水平㧍よび垂直方向の視線を計測した。 計測システムは, 眼球画像 $(320 \times 240$ 画素 $)$ を撮影する ビデオカメラと, それを処理し視線計測を行うパソコンか ら構成されている。このときのビデオカメラの撮影画角は それぞれ横約 4 度, 縦約 3 度とした。

被験者はモニ夕上に表示された水平 $3 \times$ 垂直 5 計 15 個 の各指標を注視し，その際の特性を計測した。Fig. 4 に視 線計測に用いた指標群を示す。各指標の大きさは視角にし て 1.5 度, 指標間隔は視角水平 12 度, 垂直 4.5 度である。 被験者とモニ夕間の距離は約 70 センチ（17 インチディス プレイの場合）であり，計測時に被験者はヘッドレストに 軽く頭を乗せ固定している。

水平方向視線計測特性を Fig. 5 に, 垂直方向視線計測特 性を Fig. 6 にそれぞれ 1 例ずつ示す。いずれも，横軸は指 標の位置を縦軸は視線值を示している。実験の被験者は本 システムの開発者であり，視線計測実験に慣れている。こ 


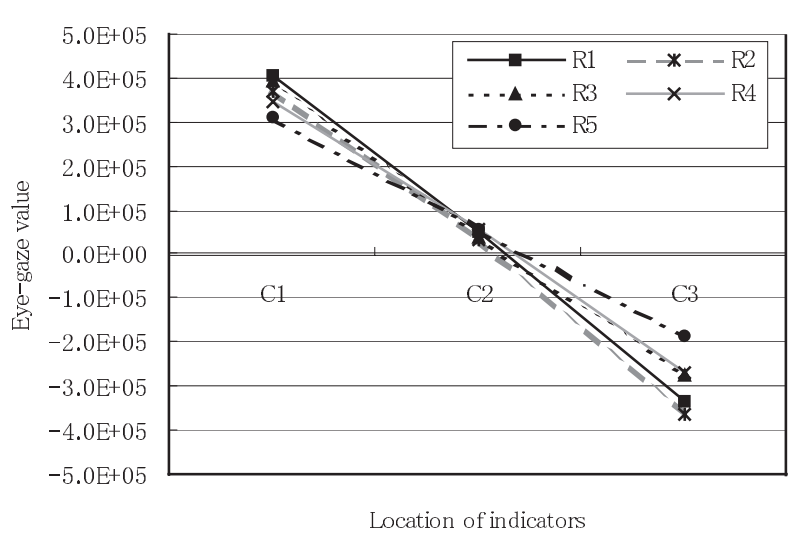

Fig. 5. Characteristics of horizontal eye-gaze measurement.

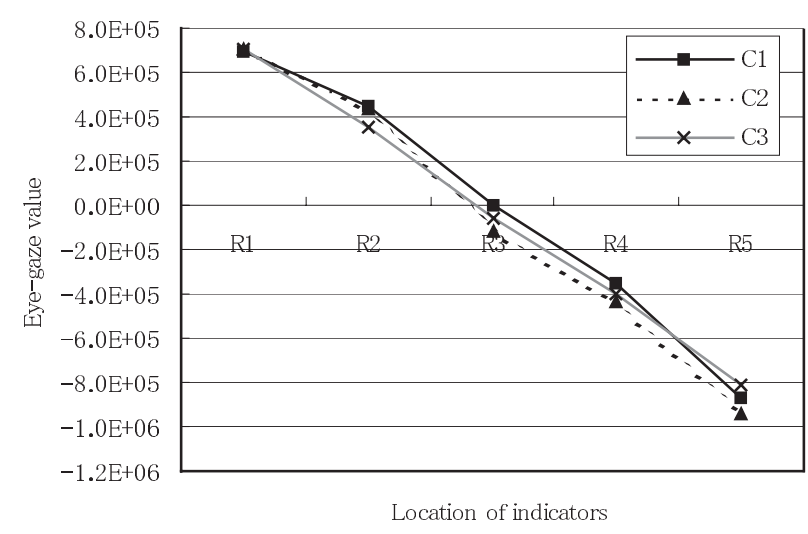

Fig. 6. Characteristics of vertical eye-gaze measurement.

の計測システムは, $\langle 3 \cdot 1\rangle$ 節で述べるマウス操作補助システ ムと同様のものである。

Fig. 5 に示す 5 本のグラフは, Fig. 3 の指標群における各 行（R1〜R5）3 個ずつの指標に対する特性, Fig. 6 に示す 3 本のグラフは, 同じくFig. 3 の指標群における各列（C1〜 C3） 5 個ずつの指標に対する特性を示している。

Fig. 5 から明らかなように, 水平方向の計測特性はいず れも直線に近いものの, 視線が下へ移動するに従い傾きが 小さくなっている。つまり，水平方向の計測特性は垂直方 向の視線移動に依存する。一方, Fig. 6 から明らかなよう に，垂直方向の計測特性も直線に近いが，視線が水平方向 に移動しても特性はほとんど変化がない。これらの計測特 性を利用して視線計測のキャリブレーションを行うが，そ の詳細は $\langle 2 \cdot 5\rangle$ 節で述べる。

$\langle\mathbf{2} \cdot \mathbf{5}\rangle \quad$ キャリブレーション 本論文で提案する視線に よるマウス操作支援システムは，モニ夕上に表示されたマ ウスカーソルをユーザの注視位置近傍へと移動させること ができる。このためには，ユーザの注視点座標を 2 次元的 に求めなければならないが，視線計測特性は個人ごとに異 なるため, システム使用前にキャリブレーションを行う必 要がある。

$\langle 2 \cdot 1\rangle$ 㧍よび $\langle 2 \cdot 2\rangle$ 節で述べたように，著者らの視線計測

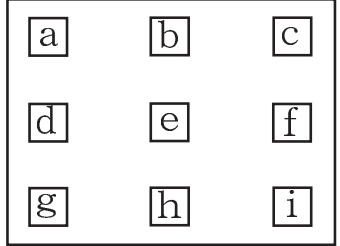

Fig. 7. Indicators for calibration.

法では, 水平抢よび垂直両方とも視線計測特性はほぼ直線 となる。しかしながら，〈2・4〉節で示したように垂直方向 の計測では視線が水平方向に移動してもほぼ等しい特性を 示すものの, 水平方向の計測では視線が垂直方向に移動す ると特性が異なってくる。これらの点を考慮し, 本システ ムのキャリブレーション指標群を設計した。キャリブレー ション指標を Fig. 7 に示す。

Fig. 7 中の “adg”, "beh”, “cfi”それぞれの指標の組か ら得られる垂直方向の視線計測特性は，いずれもほほ等し い直線となる。一方, Fig. 7 中の "abc", “def”, "ghi” そ れぞれの指標の組から得られる水平方向の視線計測特性は, いずれもほぼ直線となるが，それぞれの直線の傾きは視線 が下へ移動するに従い小さくなる。これらの点から, 著者 らは垂直方向に扔いては画面中央の “beh” の指標から得ら れた視線計測特性を代表值としてモニ夕の全領域で計測を 行い, 水平方向においては視線（注視点）の垂直方向の位 置を決定した後に計測を行うこととした。

上述のように水平方向の計測特性の傾きは，注視点の垂 直方向の位置とともに変化する。この傾きの変化と垂直方 向の視線移動はほほ比例関倸にあり，モニ夕上における任意 の注視点に扔ける水平方向計測特性は, Fig. 7 中の “abc", “def”, “ghi”それぞれの指標の組から得られた計測特性を 簡易的に線形補間することにより求められる。これにより, モニタ上いずれの位置に打いても基準となる垂直拧よび水 平方向計測特性を得ることができる。これらを利用して, ユーザの注視位置を 2 次元的に求めた。

\section{3. 視線によるマウス操作補助システム}

2 章で述べた視線計測法を用い，視線によりマウス操作 の補助を行うシステムを開発した。このシステムは，モニ 夕上のユーザの注視位置近傍へマウスカーソルを移動させ ることができ，マウスカーソル位置の微調整およびクリッ ク操作はユーザがマウスを用いて行う。

〈3・1〉 システム構成＼cjkstart著者らが開発した視線による マウス操作補助システム（以下，本システムとよぶ）は, 画像解析による視線計測を行うパソコンと眼球画像を取得 するビデオカメラから構成され，すべての視線計測処理を Windows XP 上で動作するソフトウェアで行う。1回の視 線検出に要する処理時間は約 200 ミリ秒（5フレーム/秒） であり (CPU:Pentium4, クロック周波数 $2.2 \mathrm{GHz}$ のパソ コンの場合)，実用に十分な頻度の計測が可能である。パソ コンへの動画像取达みには IEEE1394 インタフェースを用 
いディジタル入力している。またパソコンにはマウスが接 続されており，視線計測と同時にマウス操作を行うことが できる。システムの構成を Fig. 8 に, 実際のシステムの外 観を Fig. 9 に示す。

システム使用開始時にはキャリブレーション指標群が表 示され，ユーザは各指標を注視しキャリブレーションを行 う。その後に，注視点計測誤差を求める場合には水平 $5 \times$ 垂直 5 計 25 個の指標からなる指標群が表示され，マウス 操作補助を行う場合にはユーザの注視点近傍にマウスカー ソルが自動的に移動するようになる。

キャリブレーション指標群および注視点計測用指標群を Fig. 10 に示す。（a）はキャリブレーション用指標群を，(b) は注視点計測用指標群を示している。Fig. 10 に示した指標 群では，表示領域および指標の大きさを人間工学的見地か ら以下のように定めた。人の視力は視線の中心部分でもっ とも解像度が高く, 一般に眼球の中心窩（網膜上の視細胞 の密度が高い箇所で視線の中心に相当する部分）近傍 2 度 程度以内での解像度がもっとも高いとされている ${ }^{(22)}$ 。ま た，人の有効視野（頭部を移動させずに注視できる範囲） が，左右おのおの約 15 度，上約 8 度，下約 12 度であると 報告 ${ }^{(23)}$ されている。これらを参考にし，著者らの開発し ている視線入力システムでは各指標の大きさは視角にして 1.5 度（モニタ上での大きさは 70 ピクセル, 約 18 ミリで

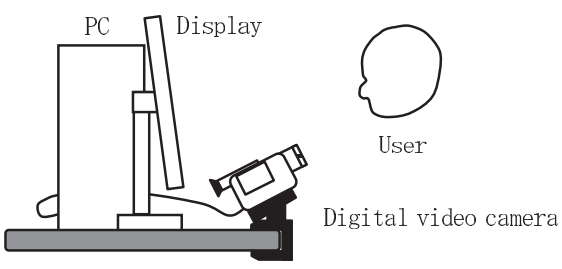

Fig. 8. Hardware configuration.

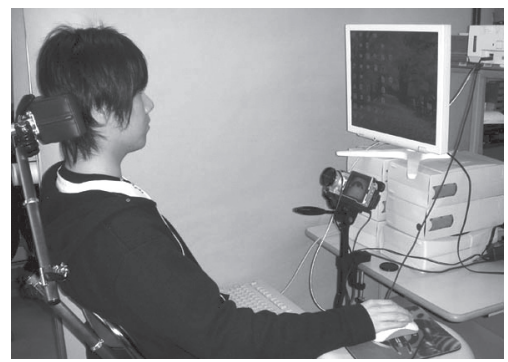

Fig. 9. Appearance of system.

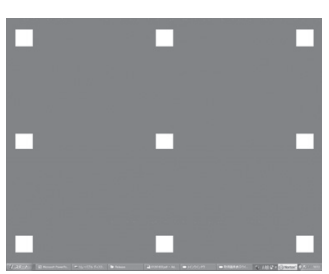

( a )

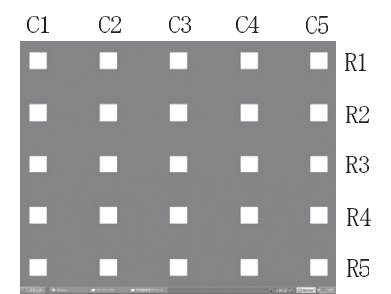

( b )
Fig. 10. Indicators for eye-gaze input system.
ある), 指標群全体の幅は, 指標の中心で水平方向 24 度, 垂直方向 18 度としている ${ }^{(16) \sim(18)}$ 。この条件では 17 イン チモニタのとき, 被験者とモニタの距離は約 70 センチと なる。また，キャリブレーションや注視点計測を行う際に は, 各指標が左上から順に白から赤に点灯し，ユーザは赤 く点灯した指標の中心を注視する。

〈3·2〉 マウスカーソル移動軌跡の平滑化 視線によ りマウスカーソルを移動させる場合, 表示されるマウスの 動きに固視微動や計測誤差に起因するぶれが生じる。その ため，手でマウスを操作したときのように，滑らかな移動 軌跡を得ることは難しい。

マウスカーソルの移動軌跡が滑らかでないと，モニ夕上 のオブジェクトヘマウスカーソルを的確に移動させること が難しいことが先行実験によって確認された。これに対処 するため, 著者らは現在および過去 2 点の注視点座標から 移動平均を求め, その移動平均值にマウスカーソルを配置 する手法を試みた。しかしながら，描画頻度をシステムの サンプリング時間に合わせ 200 ミリ秒／回としたところ, 描画速度が十分に高速ではなくマウスカーソルが飛びとび に表示され，操作が困難であった。

そこで，同じく現在および過去 2 回分の注視点座標を用 い 3 次スプライン曲線を求め, その曲線上をマウスカーソ ルが移動するようにした。このとき，描画頻度をシステム の計測頻度の倍である 100 ミリ秒／回とし，より滑らかな マウスカーソルの移動を実現することができた。

\section{4. 評価実験}

被験者 5 名（20 代男性 5 名）による本システムの評価実 験を行った。被験者 $\mathrm{A}$ は本システムの開発者であり, 視線 入力システムの操作に慣れている。被験者 $\mathrm{B} \sim \mathrm{E}$ は，本実 験ではじめて視線入力システムを使用した。実験では，本 システムの注視点計測誤差および，視線によるマウス操作 補助機能についての評価を行った。いずれの実験について も, 本システムの操作に慣れてもらうために, 実験開始前 に実験時と同様の操作を 1 回行ってもらった。

それぞれの実験開始時には，被験者に Fig. 10（a）に示 したキャリブレーション指標群の各指標を順次注視しても らい, システムのキャリブレーションを行った。

$\langle\mathbf{4} \cdot \mathbf{1}\rangle$ 注視点計測誤差についての評価実験キャリブ レーション後, Fig. 10（b）に示した 25 個の指標からなる 指標群をモニタに表示し, 各指標を 5 秒間 (25 サンプル) ずつ注視してもらい，注視点計測誤差を求めた。一般的に 注視点計測誤差を求める場合, 視対象上に 4 から 20 個程 度の指標を等間隔に配置し(11)(12)(14)(21)，被験者がその指 標を注視しているときの計測值を用いる。著者らは，水平 および垂直方向に同じ分解能で計測をするため, 水平 $5 \times$ 垂直 5 計 25 個の指標を視対象であるモニ夕（表示画面）上 に等間隔に配置した。瞬目やサッカードの潜時の影響を軽 減するため, 計測された 25 サンプルにおける視線值の中 央值近傍 21 サンプルの視線計測結果を用いた。 
Table 1. Gaze-point measurement errors (horizontal). [deg]

\begin{tabular}{c|c|c|c|c|c}
\hline \hline $\begin{array}{c}\text { Location } \\
\text { of indicator }\end{array}$ & $\mathrm{C} 1$ & $\mathrm{C} 2$ & $\mathrm{C} 3$ & $\mathrm{C} 4$ & $\mathrm{C} 5$ \\
\hline $\mathrm{R} 1$ & $0.6(0.4)$ & $0.9(0.4)$ & $0.6(0.5)$ & $0.7(0.5)$ & $1.4(1.3)$ \\
\hline $\mathrm{R} 2$ & $0.9(0.6)$ & $0.7(0.5)$ & $1.0(1.0)$ & $1.1(0.9)$ & $1.1(1.1)$ \\
\hline $\mathrm{R} 3$ & $2.1(1.0)$ & $1.4(1.9)$ & $1.1(1.0)$ & $1.3(0.8)$ & $1.7(1.2)$ \\
\hline $\mathrm{R} 4$ & $3.9(3.3)$ & $2.3(1.9)$ & $1.1(0.9)$ & $1.6(1.1)$ & $2.4(1.0)$ \\
\hline $\mathrm{R} 5$ & $4.9(5.1)$ & $1.5(1.7)$ & $2.1(1.6)$ & $2.8(2.3)$ & $2.6(1.7)$ \\
\hline
\end{tabular}

Table 2. Gaze-point measurement errors (vertical). [deg]

\begin{tabular}{c|c|c|c|c|c}
\hline \hline $\begin{array}{c}\text { Location } \\
\text { of indicator }\end{array}$ & $\mathrm{C} 1$ & $\mathrm{C} 2$ & $\mathrm{C} 3$ & $\mathrm{C} 4$ & $\mathrm{C} 5$ \\
\hline R1 & $0.9(0.4)$ & $0.8(0.5)$ & $1.1(0.7)$ & $1.2(1.4)$ & $1.2(0.8)$ \\
\hline R2 & $0.8(0.7)$ & $1.0(0.8)$ & $1.2(0.8)$ & $0.9(0.8)$ & $1.2(0.6)$ \\
\hline R3 & $1.4(1.5)$ & $1.2(1.1)$ & $1.3(0.8)$ & $1.3(0.7)$ & $0.9(0.9)$ \\
\hline R4 & $1.1(0.8)$ & $1.2(0.9)$ & $1.1(0.7)$ & $1.0(1.0)$ & $1.3(0.8)$ \\
\hline R5 & $1.7(1.3)$ & $2.8(2.6)$ & $3.2(3.4)$ & $3.0(3.8)$ & $3.1(3.3)$ \\
\hline
\end{tabular}

Table 3. Gaze-point measurement errors (total). [deg]

\begin{tabular}{c|c|c|c|c|c}
\hline \hline $\begin{array}{c}\text { Location } \\
\text { of indicator }\end{array}$ & C1 & C2 & C3 & C4 & C5 \\
\hline R1 & $1.2(0.3)$ & $1.2(0.6)$ & $1.3(0.8)$ & $1.6(1.3)$ & $2.0(1.2)$ \\
\hline R2 & $1.4(0.5)$ & $1.2(0.8)$ & $1.8(0.9)$ & $1.7(0.5)$ & $1.9(0.7)$ \\
\hline R3 & $2.7(1.5)$ & $2.0(2.0)$ & $1.8(1.2)$ & $1.9(0.9)$ & $2.0(1.3)$ \\
\hline R4 & $4.4(2.8)$ & $2.8(1.5)$ & $1.6(1.1)$ & $2.0(1.3)$ & $2.8(1.1)$ \\
\hline R5 & $5.6(4.8)$ & $3.6(2.4)$ & $4.3(3.0)$ & $4.6(3.8)$ & $4.5(2.9)$ \\
\hline
\end{tabular}

被験者 5 名による注視点計測誤差の平均および標準偏差 を Table 1 3 に示す（括弧内は標準偏差）。Table 1 およ びTable 2 は，それぞれ水平方向と垂直方向についての誤 差を, Table 3 は水平抢よび垂直方向の誤差から求めた総 合的な誤差（指標中心と計測点座標の距離）示している。 Table 1〜3において注視点計測誤差は視角で表しており， それぞれの表の項目は Fig. 10（b）に示した指標位置と対 応している。また, Table 1〜3に示したデータのうち注視 点計測誤差の平均を Fig. 11〜13に示す。

Table 1 拈よびTable 2 から明らかなように, 水平抢よび 垂直両方向の視線計測においても, 視線が下へ移動するに 従い注視点計測誤差は増加している。この原因として, 視 線移動によって上まぶたが下がり，眼球開口部が暗く撮影 されることがあげられる。眼球開口部が暗く撮影されると， 視線が下に移動するに従い, 水平方向の視線計測特性の傾 きが小さくなる，つまり視線移動に対する視線值の変化が 小さくなるため, 水平方向の計測誤差が増加することが考 えられる。また垂直方向に扔いても同様に, 計測領域にお ける光強度積分值の差は眼球開口部が明るい場合に比べ小 さくなるため, 計測誤差が増加するものと考えられる。

また，垂直方向に抢ける注視点計測誤差の増加の原因と して，視線を何度か移動させるたびに眼球開口部の形状が 微妙に変化することがあげられる。この変化は $2 \sim 3$ ピクセ ル程度のものであるが, 計測領域の面積が数パーセント増 減するため計測に影響を与える。垂直方向の計測では, 計 測領域の上下辺の位置を上下まぶたの位置としているが, 計測のたびにまぶたの形状が変化すれば計測領域の面積も

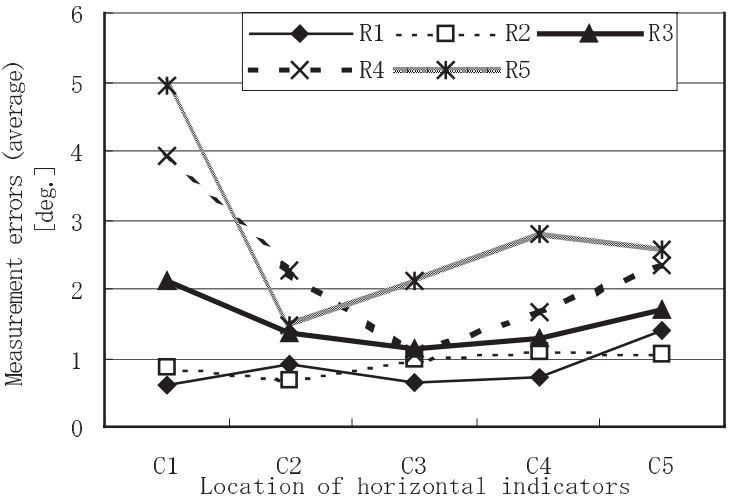

Fig. 11. Gaze-point measurement errors(horizontal).

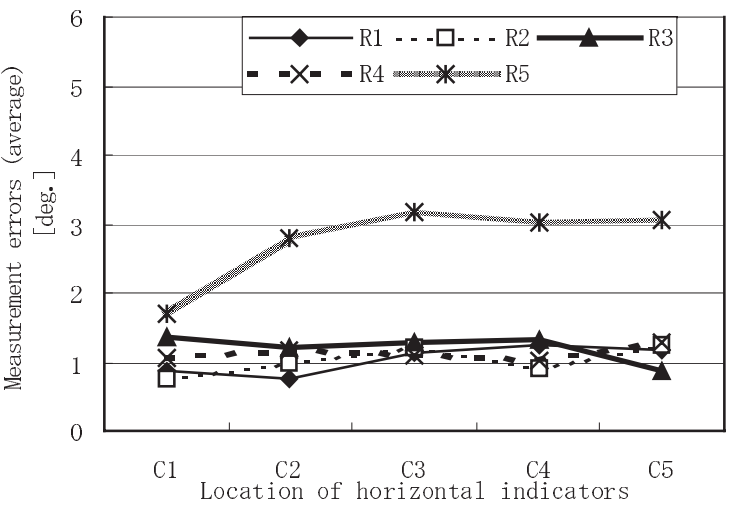

Fig. 12. Gaze-point measurement errors(vertical).

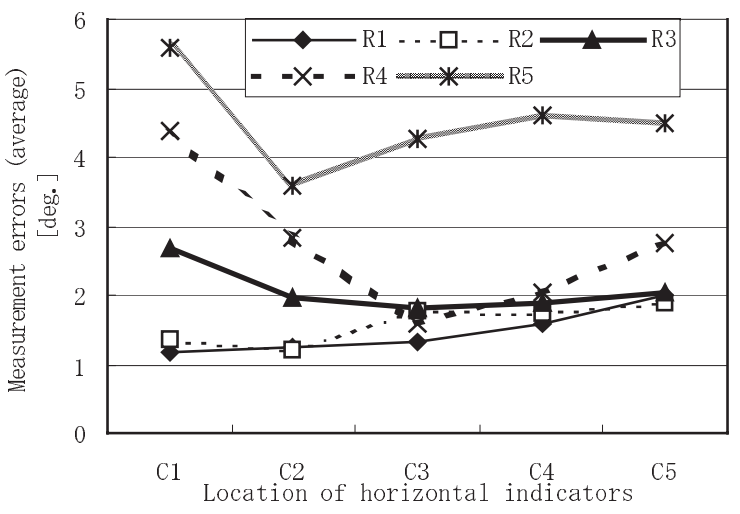

Fig. 13. Gaze-point measurement errors(total).

変化し，誤差につながるものと考えられる。

Table 3 の結果から求められるように, 注視点計測誤差の 被験者 5 名の平均值は約 2.5 度である。視線入力のような VDT 作業中に生じる固視微動は, 最大で視角にして約 0.5 度と報告されている ${ }^{(20)}$ 。また，本論文と同一条件である 1 台のカメラによる自然光下に扔ける手法ではたかだか数個 の指標を識別するのみであり ${ }^{(8) \sim(10)}$, 特殊な点光源を用い た方法でも計測精度は土 0.5 0.9 度である ${ }^{(19)}$ 。これら を考慮すると，提案した手法は 1 台のカメラを用い特殊な 照明を使用せずに，比較的高精度な視線計測を行うことが できる。本実験では Fig. 14 に示す実験画像のように, 虹 彩が半分以上まぶたの下に隠れてしまう被験者もいたが，2 


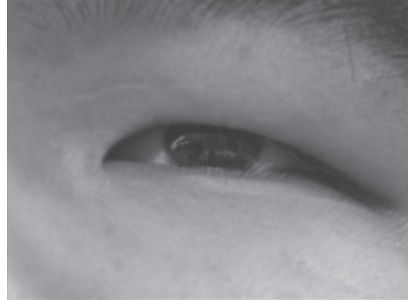

Fig. 14. A typical eye image hidden by eyelids.

章で提案した手法によるといずれの被験者においても視線 計測が可能であることが確認できた。また，著者らの視線 入力の従来システムでは高精度の垂直方向の視線計測のた めには多くのキャリブレーション指標を必要としたが，本 手法では 9 個という比較的少ない指標でキャリブレーショ ンを行うことにより，ユーザの注視点の座標を 2 次元で求 められるようになった。これは, 多様なアプリケーション への拡張を考慮する際に大きな利点となる。

本システムではマウスカーソルを注視位置近傍へ移動さ せるが，マウス操作による選択対象の大きさを適切に設定 すると, 約 2.5 度の注視点計測誤差で十分な操作を行うこ とができる。また，精密なカーソルの位置合わせが必要な 場合は，マウスカーソルが対象に近づくようさらに視線を 移動させる, 健常者向けのアプリケーションでは手動操作 で補完するなどの方法で対処できる。

$\langle\mathbf{4} \cdot 2\rangle \quad$ マウス操作補助機能についての評価実験 キャ リブレーション後，モニタ上に円形指標をランダムに表示 し，被験者に視線でマウスカーソルを指標まで移動しても らい, その際の所要時間を計測した。実験では, 目的地の 指標上にマウスカーソルが到達し，5 サンプルの計測の間 にカーソルがその指標上に位置し続けると，移動させるこ とができたと判定した。判定後，新たな指標が表示される。 このとき，マウスカーソルの移動は視線のみで行った。注 視点とマウスカーソルの位置に誤差がある場合は, 注視位 置を適宜調整し，指標上にマウスカーソルが位置するよう に操作してもらった。

指標の大きさは直径が視角にして 4 度（モニタ上での大 きさは 185 ピクセル，約 50 ミリである）であり，これは Table 3 に示した注視点計測誤差から決定した。指標の大 きさが大きいほど，指標選択の精度は向上しその操作時間 も短くなる。指標の大きさは注視点計測誤差の 2 倍以上が 望ましい(15) が，本システムでは被験者が注視位置を適宜 調整するため，モニタの表示領域の大きさを考慮し指標の 大きさを 4 度とした。〈3・1〉節で述べたように，眼球の中心 窩は 2 度程度であるため, それより大きい指標は注視しに くいと感じる被験者もいる。しかしながら，本実験におい て被験者のおもな注視対象はマウスカーソルであり，これ は中心窩に比べて十分小さい。そのため，被験者は問題な く視対象を注視することができた。本実験に使用した指標 の表示例を Fig. 15 に示す。

実験時，指標の中心座標は乱数により決定され，指標は

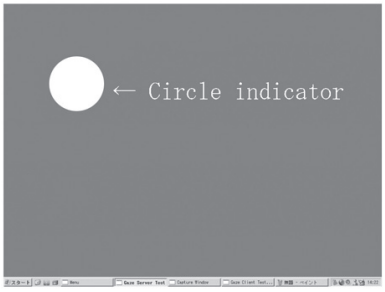

Fig. 15. Indicator for evaluation of mouse operation.

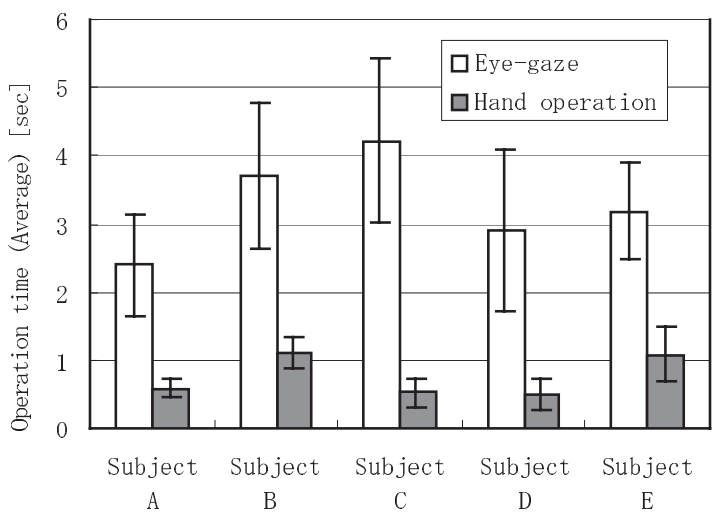

Fig. 16. Time of mouse cursor movement.[sec].

9 回ランダムに表示される。9 回のうち, 同一座標が指定さ れることはない。指標間の移動に要した時間を計測し，同 様の作業をマウスによる手操作で行った場合と比較した。 被験者 5 名による実験結果の平均と標準偏差を Fig. 16 に 示す。

実験の結果，いずれの被験者においても，本システムを 用いることにより目的の指標へ視線でマウスカーソルを移 動させることができた。Fig. 16 から明らかなように，視線 によるマウスカーソル移動時間は，マウスの手操作による 結果の約 4 倍となることがわかる。これは，〈3・2 節で述べ たように, マウスカーソルの移動軌跡を現在と過去 2 回の 計測結果を基に平滑化しているため, 取得画像の 2 フレー ム分（約 400 ミリ秒）遅れでマウスカーソルが移動してい るためである。また，視線のみによる場合と手操作による 場合では，所要時間の標準偏差が大きく異なる。いずれの 被験者においても，手操作の方が視線のみに比べて標準偏 差は小さい。これは手操作に比べ視線によるマウスカーソ ルの操作は経験が少ないため, 操作時間のばらつきが多い ためだと思われる。

赤外線を用いた視線入力システムには，著者らの提案す るシステムと同様に, ユーザの注視位置を 2 次元座標とし て計測するものが多数報告されている。これらのシステム には，注視状態をより的確に識別するためにガイド領域を 設けたり (4)，10〜15 個程度の指標を配置した指標群を切り 換えて ${ }^{(5)}$ 文字入力を行うもの, マウスカーソルを操作し画

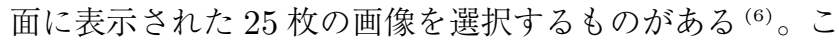
れらは赤外線照明や特殊な視線計測装置を用いて高頻度に 視線計測を行い，1 選択あたり約 2 秒と高速な入力を実現 
している(5)(6) が, 選択誤差を軽減するために 1 選択あた り約 4 秒を要するものもある (4)。いずれのシステムも評価 実験の条件が異なるため比較は難しいが，著者らのシステ ムは赤外線照明などの特殊な装置を用いずに，一般的なパ ソコンとビデオカメラ 1 台のみで実用上十分な指標選択が できることがわかった。

今回の実験では，表示される指標が瞬時に移動するため 被験者の視線は大きく移動し, 跳躍運動に近い動作をした。 これは, カーソル移動時の描画の遅延の影響が大きいため である。しかしながら実際のアプリケーションでは，選択 の対象となるオブジェクトを探索しながら視線を移動させ るため, この遅延による操作性に対する影響は少ないと考 えられる。また，本システムを使用する際は，選択したい オブジェクトの近傍へマウスカーソルが移動すれば，あと はマウスによる手操作でカーソル位置を微調整できる。そ のため, 本実験よりもさらに短い時間でオブジェクトを選 択できるものと考えている。

\section{5. まとめ}

著者らは，自然光下で 1 台のビデオカメラにより撮影さ れた眼球画像から，画像解析により水平抢よび垂直方向の 視線を計測する新しい視線入力システムを提案してきた。 処理手順は単純であり，赤外線照明などの特殊な装置を用 いないため, システムは小形で汎用性が高い。

今までに開発してきた視線入力システムは, 水平方向の 視線を高精度に計測することは可能であったが，垂直方向 は上中下の 3 方向の識別のみをしていた。これは視線が垂 直方向に移動すると上下まぶたの位置が変化し, 計測領域 に眼球以外の部分が入り込み, 高精度な計測が困難であっ たためである。この点を改善するため, 眼球形状の情報か ら眼球開口部の上端および下端，すなわち上下まぶたの位 置を求め, 垂直方向の視線移動に合わせて計測領域の位置 を修正する手法を開発した。これにより，垂直方向の視線 をより精度よく計測することができるようになった。また， 垂直方向に打いても水平方向と同様に強膜反射法を応用す ることにより，ユーザの注視点位置の 2 次元座標を計測す ることが可能となった。これはアプリケーションの拡張へ の大きな利点となる。たとえば，著者らの従来の視線入力 システムは，システムが画面に表示する指標のみの選択操 作を目的としているが，提案した手法はモニ夕上の任意位 置に配置されているWindows のアイコンやウインドウな どのオブジェクトの選択に応用できるため, 一般的なアプ リケーションソフトウェアを利用する際の操作性は格段に 向上する。

この新しい視線計測法の応用として, ユーザの注視位置 近傍にマウスカーソルを移動させるマウス操作補助システ ムを構築した。このシステムの有用性を確認するため, 被 験者 5 名による評価実験を行った。実験では, 注視点計測誤 差と視線によるマウス操作補助機能を使用した際の所要時 間を求めた。その結果，注視点計測誤差は平均で約 2.5 度と
なり，たかだか数個の指標を認識するのみの，他の自然光 下に扔ける手法 ${ }^{(8) \sim(10)}$ に比べ, 高精度であることが確認さ れた。自然光下に拝いても点光源とその角膜反射像を用い, 計測誤差が水平方向では 0.5 度, 垂直方向では土 0.9 度 と本システムに比べて精度が高い手法 (19) も提案されてい るが，著者らの提案する視線計測法では一般的な室内照明 のみで使用できるという利点がある。また，選択したいオ ブジェクトまで視線でマウスカーソルを移動させると, マ ウスの手操作に比べ約 4 倍の時間を要するものの, 視線の みで操作できることを確認した。本システムは, Pentium 4 (クロック周波数 $: 2.2 \mathrm{GHz}$ ) という旧世代のプロセッサ を搭載したパソコンで動作している。現在，普及が進んで いるデュアルコア以上の複数のコアをもつプロセッサを用 いると, より高頻度の計測が可能になるものと考えている。 今後はこのようなプロセッサを用い, 視線計測ソフトウェ アの最適化も行い，より高速に視線による操作を行うこと ができるシステムを開発したい。

現在のシステムは眼球近傍を拡大し撮影しているため, 撮影フレームから眼球が外へ出ないように被験者の頭部を 軽く支えている。今後は, 高解像度のハイビジョンビデオ カメラなどを用い，顔全体を撮影して眼球近傍を抽出する ことにより頭部の移動を許容するシステムを開発し，健常 者も使用できる一般的な視線によるインタフェースを構築 することを目指している。また，注視点計測精度をより向 上させ, 幅広い実験環境下で認知心理学実験などにも利用 できる視線計測システムへと発展させたい。

(平成 20 年 10 月 20 日受付, 平成 21 年 5 月 8 日再受付)

\section{文献}

（1）山田光穗・福田忠彦：「眼球運動による文章作成・周辺機器制御装 置」, 信学論, J69-D, 7, pp.1103-1107 (1986-7)

(2) T.E. Huchinson, K.P. White, JR., W.N. Martin, K.C. Reichert, and L.A. Frey: "Human-Computer Interaction Using Eye-Gaze Input", IEEE Trans. Systems, Man, and Cybernetics, Vol.19, No.7, pp.1527-1534 (1989-12)

（3）伊藤和幸. 数藤康雄 - 伊福部達 : 「重度肢体不自由者向け視線入力 式コミュニケーション装置」, 信学論, J83-D1，5，pp.495-503 (2000-5)

（4）坂尚 幸·菅又生磨・板倉直明・坂本和義・北本 拓:「ガイド領域 を用いた視線文字入力インタフェース」，信学論，J84-D-II, 5, pp.799-804, (2001-5)

（5）青木洋貴・伊藤謙治・J.P. Hansen :「日本語文字入力のための注視 ンタフェースに対する学習容易性評価」, 人間工学, Vol.41, No.2, pp.65-76, (2005-4)

(6) O. Oyekoya and F.W.M. Stentiford: "A Performance Comparison of Eye Tracking and Mouse Interfaces in A Target Image Identification Task", Proc. on The 2nd European Workshop on the Integration of Knowledge, Semantics and Digital Media Technologies (EWIMT 2005), pp.139-144 (2005-11,12)

（7）落合 積・石松隆和・高見修・松井稜治：「目の動きを利用した 身障者用文字入力装置の試作」, 機学論 C 編, Vol.63, No.609, pp.1546-1550 (1997-5)

（8）岸本研志・米村貴裕・広瀬健一・長江貞彦:「カーソル移動方式による 視線入力システムの開発」, 映情学誌, Vol.55, No.6, pp.917-919 (2001-5)

(9) F. Corno, L. Farinetti, and I. Signorile: "A Cost-Effective Solution for Eye-Gaze Assistive Technology", Proc. IEEE International Conf. on Multimedia and Expo, 2, pp.433-436, Lausanne, Switzerland (2002-8) 
（10）伊藤和幸・伊福部達：「ビデオキャプチャ画像処理による視線検出 及び意思伝達装置への応用」, 信学論, J88-D1，2，pp.527-535 (2005-2)

（11）西内信之·柴田 碧・高田 一：「画像処理による非接触視線検出 法の研究」, 機学論 C 編, Vol.64, No.620, pp.121-127 (1998-4)

（12）西内信之・高田一・栗原謙三：「カラーコンタクトレンズを利 用した非接触視線検出法の研究」, 機学論 C 編, Vol.65, No.636, pp.282-288 (1999-8)

(13) Y. Matsumoto and A. Zelinsky: "An Algorithm for Real-time Stereo Vision Implementation of Head Pose and Gaze Direction Measurement", Proc. IEEE Forth International Conf. on Face and Gesture Recognition, pp.499-505 (2000-3)

(14) J. G. Wang and E. Sung: "Study on Eye Gaze Estimation", IEEE Trans. on Systems, Man and Cybernetics, 32, 3, pp.332-350 (2002-1)

（15） 阿部清彦 · 大内幹夫 ·大井尚一・大山 実：「画像解析による強 膜反射法を用いた視線入力システム」, 映情学誌, Vol.57, No.10, pp.1354-1360 (2003-10)

(16）阿部清彦·大山 実·大井尚一:「自然光下における画像解析を用いた多 指標視線入力システム」, 映情学誌, Vol.58, No.11, pp.1656-1664 (2004-11)

（17）阿部清彦·大和田厚祐・大井尚一・大山 実:「視線入力による Web ブラウザ」，電学論， 127-C，7,pp.1036-1042 (2007-7)

（18）阿部清彦・佐藤寛修・大山 実・大井尚一：「視線による重度肢体 不自由者向けコンピュータ操作支援システム」, 映像情報メディア 学会誌, Vol.60, No.12, pp.1971-1979, (2006-12)

（19）竹上 健 ·後藤敏行 :「角膜反射像と虹彩輪郭情報を併用した視線 検出法」, 信学論, J82-D1, 10, pp.1295-1303 (1999-10)

(20) 竹上 健·後藤敏行·大山 玄:「視線方向検出におけるセルフキャリ ブレーションに関する研究」, 信学論, J84-D2, 8, pp.1580-1588 (2001-8)

（21） 久野悦章・八木 透·藤井一幸・古賀一男·内川嘉樹:「EOG を用いた 視線入力インタフェースの開発」, 情処学論, 39, 5, pp.1455-1462, (May 1998)

（22）乾 敏郎：「視覚情報処理の基礎」, サイエンス社, pp.11-19 (1990)

（23）野呂影勇 (編):「図説エルゴノミクス」, (財) 日本規格協会, pp.288292 (1990)

阿 部 清 彦 (正員) 1977 年生。2000 年 東京電機大学工学部

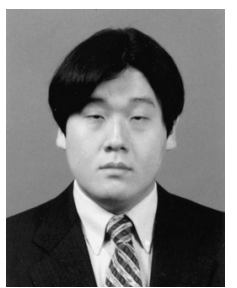
卒業。2005 年 同大学大学院博士課程修了。同年 同大工学部助手。2006 年 関東学院大学工学部技 師補。現在同助教。博士 (工学)。画像解析, 視 線入力に関する研究に従事。
仲 山 泰 弘 (非会員) 1985 年生。2008 年 東京電機大学工学

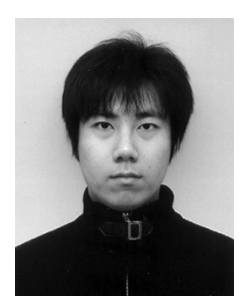
部卒業。在学中, 画像解析と視線入力に関する研 究に従事。現在, アミューズメントメディア総合 学院在学中。

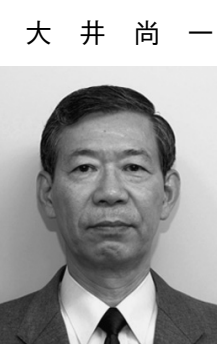

（非会員） 1939 年生。1962 年 東京電機大学工学 部卒業。1968 年 同大学大学院博士課程修了。同 年 同大工学部専任講師。現在同教授。工学博士。 計算機応用, 縞画像解析 (光弾性縞, モアレ等高 線縞), 視線入力, 教育工学等の研究に従事。

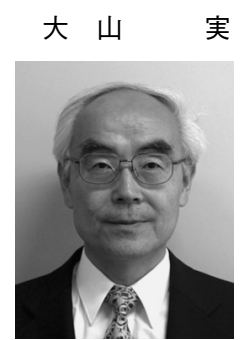

実（非会員） 1949 年生。1972 年 東京電機大学工学 部卒業。1975 年 同大学大学院修士課程修了。同 年日本電信電話公社 (現 NTT) 入社。1998 年 電 気通信大学大学院客員教授。現在, 東京電機大学 情報環境学部教授。工学博士。番号案内, 音声 . 言語処理応用, パーソナル通信, 視線入力等の研 究に従事。 